\title{
CONTROL AND ACCOUNTING INFORMATION SYSTEM USING COSO ERM IN PT. EMII
}

\author{
Faiz Syahputra \\ Faculty of Business Administration and Humanities \\ Swiss German University, Tangerang, Indonesia \\ syahputrafaiz@rocketmail.com
}

\author{
Imelda Suardi \\ Faculty of Business Administration and Humanities \\ Swiss German University, Tangerang, Indonesia \\ imelda.suardi@sgu.ac.id
}

The use of accounting information system effects the implementation of internal control. COSO ERM method is now the most widely accepted internal control framework in the world and used as the basis for this research. The case study was conducted in a medical equipment distributor that has implemented accounting information system for their financial reporting. The focus is on its process, threats, and controls using interview and questionnaire to the employess. This research proposed new procedures for both revenue and expenditure cycles and suggested activites for better internal control. The result showed that the company has implemented good internal control in almost all COSO ERM measurement, except for information and communication aspect.

Accounting Information system, internal control, financial report 


\section{INTRODUCTION}

\section{I.1. BACKGROUND}

$\mathrm{I}$ $n$ the globalization era, information technology plays an essential role in the finance world. Technology has been pivotal in helping accountants, businessmen, and directors in managing and giving direction regarding where a company wants to go. As stated by Brynjolfsson and Hitt (2000), information technology is defined as computers as well as related digital communication technology, which has the broad power to reduce the costs of coordination, communications, and information processing. Facing this most high technology then an accounting information system is one of the technologies that a company will need to invest in their future business. This technology is very helpful in many ways for business practices including in the accounting field. Therefore, the application of Accounting Information System (AIS) in the business sector should be encouraged and applied for the advantages of business sustainability.

Management and employees of the company will get benefit from the effect of AIS implementation on the revenue cycle and expenditure cycle of their business. Both cycles are important for management. The revenue cycle's primary objective is to provide the right product in the right place at the right time for the right place. Whereas the primary objective of the expenditure cycle is to minimize the total cost of acquiring and maintaining inventories, supplies, and the various services the organization needs to function.

Research on AIS is very challenging because the implementation of AIS currently is very useful for business sector. Based on some experiences, the use of AIS will benefit in successful implemention of Internal Control Frameworks (ICF). The Committee of Sponsoring Organizations of the Treadway Commission's (COSO) Enterprise Risk Management method will be used as the basis for this research, and it is now the most widely accepted internal control framework in the world. In 1990s COSO Internal ControlIntegarated Framework (ICIF) developed five components and additional three components of ERM in early 2000, namely control environment, risk assessment, control activities, information and communication, monitoring, objective setting, event identification, and risk response.

This research uses the enterprise resource management model to discuss about internal controls. The more understanding about enterprise resource management model will give beneficial to the more easy to understand about internal control (IC) model.

This research was conducted in a company that has experience about a year in implementing AIS. PT. EMII was selected as the case study for this research. The company was founded in 1977, and since then it had focused on supplying medical tools such as orthopedic appliances for hospitals, laboratories and doctors all over Indonesia. PT. EMII categories as a small medium enterprise (SME), has been implemented a new accounting information system since 2014. Small medium enterprises usually don't pay much attention to internal control because amount of loss occurred due to the weakness of internal control that results from fraudulent activities is not that high.

\section{I.2. RESEARCH OBJECTIVES}

Based on the research problems, the research objectives are: 
1. To analyze the revenue and expenditure cycle of PT. EMII based on accounting information system processes, threats, and controls.

2. To evaluate the company's internal control using COSO's Enterprise Risk Management model.

3. Propose for the new revenue and expenditure cycle and give recommendation for better internal control in PT. EMII.

\section{I.3. SIGNIFICANT OF STUDY}

This study will be significant in the following ways:

\section{For company}

Both the management and employees of the company will understand the effect of AIS implementation on the revenue cycle and expenditure cycle. The results of this research will give additional suggestions and recommendations about internal control and its importance to PT. EMII.

\section{For future researchers}

This research will prove to be important for other academicians that intend to continue study of the COSO enterprise risk management model to other industries.

\section{LITERATURE STUDY}

\section{II.1. GENERAL THEORIES}

\section{II.1.2. ACCOUNTING INFORMATION SYSTEM}

Accounting information systems is a tool that organizations can use to achieve stronger, more flexible corporate culture to face continual changes in the environment (Jawabreh, 2012). Furthermore, according to Romney and Steinbart (2006), an accounting information system (AIS) is a system that collects, records, stores, and processes data to produce information for decision makers.

Romney and Steinbart (2006) mention that there are six components of AIS which are the people who operate the system and perform various functions, the procedures and instructions, both manual and automated, the data about the organization and its business processes, the software used to process the organization's data, the information technology infrastructure and the internal controls and security measures that safeguard the data in the AIS.

Together, these above six components enable an accounting information system (AIS) to fulfill three important business functions:

1. Collect and store data about organizational activities, resources, and personnel.

2. Transform data into information that is useful for making decisions so management can plan, execute, control, and evaluate activities, resources, and personnel.

3. Provide adequate controls to safeguard the organization's assets, including its data, to ensure that the assets and data are available when needed and the data is accurate and reliable (Romney and Steinbart, 2006).

Accounting Information Systems don't just support accounting and finance business processes. They often create information that is useful to nonaccountants. For this information to be effective, the individuals working in these subsystems must help the developers of AIS identify what information they need for their planning, decision making, and control functions (Bagranoff, Simkin and Norman, 2010). 
Accounting information systems- as part of the management information systemsrepresent one of the most important systems in the economic unity and these organizations are vary among each other in terms of the application of accounting information systems and the consciousness of their importance (Abdallah, 2013).

According to Alsharayri in Mndzebele (2013), the benefits of accounting information systems can be measured by its impact on improvement of the decision making process, quality of accounting information performance evaluation, internal control, and facilitating company's transactions. Sambasivam, Y. and K.B. Assefa (2013) mention that AIS design and implementation could make possible the enhancement of quality of financial report; system design could affect quality of AIS implementation; AIS design and implementation could facilitate financial transaction processes, lead to better decision-making by managers, enable to have more effective internal control systems.

\section{II.1.2. REVENUE CYCLE}

A repeatable set of business activities associated with providing goods and services to customers and collecting cash in payment for those sales is called revenue cycle based on Romney and Steinbart (2015). The objective is to provide the right product in the right place at the right time for the right place which is because of their primary external exchange of information is with customers.

The revenue cycle is a recurring set of business activities and related information processing operations associated with providing goods and services to customers and collecting cash in payment for those sales, where the primary external exchange of information is with customers.
Information about revenue cycle activities also flows to the other accounting cycles which are Sales Order Entry, Shipping, Billing, and Cash Collection.

\section{II.1.3. EXPENDITURE CYCLE}

The expenditure cycle is a recurring set of business activities and related information processing operations associated with the purchase of and payment for goods and services. In the expenditure cycle, the primary external exchange of information is with suppliers (vendors). Within the organization, information about the need to purchase goods and materials flows to the expenditure cycle from the revenue and production cycles, inventory control, and various departments. Once the goods and materials arrive, notification of their receipt flows back to those sources from the expenditure cycle. Expense data also flow from the expenditure cycle to the general ledger and reporting function for inclusion in financial statements and various management reports.

The activities in the expenditure cycle are mirror images of the basic activities performed in the revenue cycle. These close linkages between the buyer's expenditure cycle activities and the seller's revenue cycle activities have important implications for the design of both parties' accounting information systems. (Romney and Steinbart, 2015).

\section{II.1.4. INTERNAL CONTROL}

According to Mndzebele (2013), internal controls are run to ensure the achievement of operational goals and performance.

According to Arens, Elder and Beasley (2012), reasonable assurance means a developed internal control that provide reasonable, but not absolute, assurance that the financial statements are fairly stated. 
According to Bagranoff, Simkin and Norman (2010), internal control describes the policies, plans, and procedures implemented by management of an organization to protect its assets.

Beasley, Clune, and Hermanson (2005) found that ERM implementation is positively correlated to the presence of a chief risk officer, board independence, $\mathrm{CEO}$ and $\mathrm{CFO}$ support, presence of Big Four auditor, and entity size.

The IC framework has been widely adopted as the way to evaluate the internal controls, as required by SOX (Sarbanes-Oxley Act) in USA. The more comprehensive Enterprise Risk Management framework takes a risk-based rather than a controls-based approach. Enterprise risk management adds three additional elements to COSO's IC framework: setting objectives, identifying events that may affect the company, and developing a response to assessed risk (Romney and Steinbart, 2015).

In contrast, the auditor's responsibilities for internal control include understanding and testing internal control over financial reporting. To comply with the second standard of fieldwork, the auditor focuses primarily on the controls related to the first of management's internal control concerns: reliability of financial reporting (Arens, Elder and Beasley, 2012).

In determining and assessing the quality of internal control over financial reporting, a comprehensive framework must be used as is the case with GAAP that always stated as a basis for determining whether a company financial statements are fairly stated or not (Gramling, Rittenberg and Johnstone, 2010). Whereas COSO defines internal control as a process, affected by an entity's board of directors, management, and other personnel, designed to provide reasonable assurance regarding the achievement of objectives in the following categories, reliability of financial reporting, compliance with applicable laws and regulations, and effectiveness and efficiency of operations.

\section{II.1.5. COSO ENTERPRISE RISK MANAGEMENT}

Since the mid-1990s, enterprise risk management (ERM) has emerged as a set of ideas for rethinking the organization of risk management activities (Power, 2005). According to the COSO report, an internal control system should consist of these five components:

1. The control environment

2. Risk assessment

3. Control activities

4. Information and communication, and

5. Monitoring (Bagranoff, Simkin and Norman, 2010).

Enterprise Risk Management - Integrated Framework (ERM) is the process the board of directors and management use to set strategy, identify events that may affect the entity, assess and manage risk, and provide reasonable assurance that the company achieves its objectives and goals (Romney and Steinbart, 2015). One advantage ERM has over traditional risk management activities, which evaluate risks within a particular department or function. Thus, ERM looks at the risks of the firm as a whole and cross-functionally (Mikes, 2011),

The 2004 COSO Enterprise Risk Management - Integrated Framework focuses on enterprise risk management (ERM) and builds upon the 1992 COSO Internal Control - Integrated Framework (ICIF). The ERM Framework includes the five components of ICIF 
(control environment, risk assessment, control activities, information and communication, and monitoring) and adds three additional components: objective setting, event identification, and risk response (Bagranoff, Simkin and Norman, 2010).

\section{II.1.6. MEDICAL EQUIPMENT BUSINESS}

In 2008, the number of hospitals in Indonesia reaches 1320 hospitals (Ministry of Health, 2009), or an increase of 86 hospitals from the position in 2003. Of the 1320 hospitals that number, 657 of them private with the average growth per year the number of hospitals around $1.14 \%$. The rest is a hospital built by the government $(\mathrm{MOH}$, provincial/ district/ city government, Army/ Police, and SOE).

Undeniably, the entry of foreign investors, the development of upper middle-class population, increasing per capita income level, and increasingly important in maintaining public health and choose where to seek treatment is one of the reasons for the increasing trend of development of this class hospital. (Abadinusa, 2009).

As the fourth most populous country in the world, Indonesia offers great potential for the medical equipment and supplies market. The market shows consistent growth of 10 to 20 percent. In the last two years from 2007 to 2008, the total imports of medical equipment grew from $\$ 332$ million to $\$ 369$ million. The U.S. is the largest exporter of medical equipment to Indonesia accounting for over 15 percent of total imports. Import duties ranging from $0-5$ percent are imposed on medical equipment and supplies. A VAT of 10 percent is imposed on all imported products. U.S. companies must appoint an agent or a distributor to register and sell their products in Indonesia (http://export.gov/industry/ health/healthcareresourceguide/ indonesia084191.asp).

With over 237 million people and steady economic growth, Indonesia presents excellent opportunities for U.S. companies. Increases in public awareness in healthcare and social conditions and the expansion of public and private hospitals have led to increased demand for more sophisticated and modern medical equipment and supplies. In 2009, medical equipment imports grew at a robust rate of 15 percent, with U.S. imports accounting for over 14 percent of this market. Continued strong growth for this market is predicted over the next two years.

Total imports of medical equipment grew from $\$ 508$ million in 2009 to \$543 million in 2010, with U.S. imports accounting for $20 \%$ of this market. Continued strong growth for this market is predicted over the next two years. U.S. manufacturers of medical devices should take advantage of this growing market. (http://export.gov/industry/health/ healthcareresourceguide/indonesia084191. asp)

\section{II.2. PREVIOUS STUDIES}

There were number of studies had been conducted in the area of accounting information system and internal control as well as how this accounting information system may contribute to the internal control of certain sectors.

Differences between previous studies with this research paper are this research paper discusses about internal control using ERM model about medical equipment business in Indonesia and discusses about process, threats, and controls of cycles, revenue and expenditure. 


\section{METHODOLOGY}

\section{III.1.POPULATIONAND SAMPLING}

The target population for this research was all employees working for PT. EMII.

\section{III.2. RESEARCH MODEL}

Figure 1. Research Model

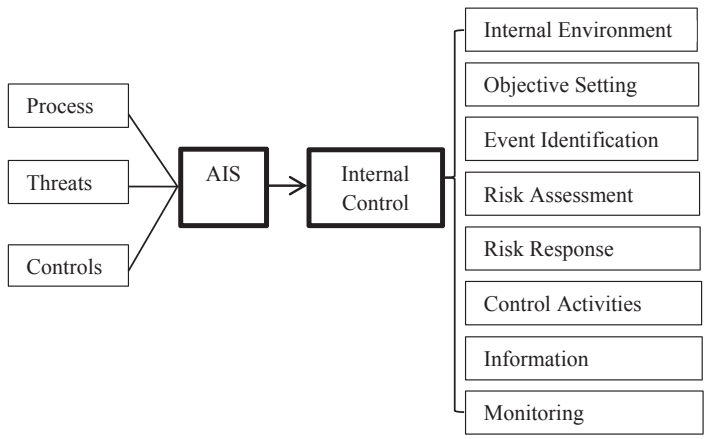

\section{III.3. METHOD OF DATA} ANALYSIS

Data for the research was collected through questionnaire application, interview and observation. Respondents for the questionnaire including marketing manager, sales, head of finance, finance staff, and secretary of PT. EMII. All of them received the same questions. In addition to the questionnaire, $\quad \mathrm{th} \mathrm{e}$ interview has conducted for this research. The director of PT. EMII has asked for several questions. The observation was conducted to understand the process of revenue cycle and expenditure cycle while also examining the potential threats on those cycles. It was conducted by visiting the company, talking with the managers (both finance manager and marketing manager), and also the director. In analysis the research, literature was used as basic theories to support the research. This research mostly used theories taken from various accounting information system and auditing books and journals. Romney and Steinbart (2015) provided theories regarding the COSO Enterprise Risk Management Model.

\section{III.4. HYPOTHESIS}

There are some hypothesis will be tested for this research as follows:

1. The implementation of company's internal control are not performed well based on COSO ERM.

2. The control activities in revenue and expenditure cycle are not implemented well to minimize the weakness or threats.

3. Need to propose the better cycles and give recommendation to the internal control.

\section{III.5. DATA PROCESSING AND ANALYSIS}

The data gathered are resulted from questionnaire and interview. Questions in the questionnaire were focused on accounting information systems (AIS) and internal controls. In order to describe the process of a revenue cycle and expenditure cycle, then flowchart was used.

Descriptive analysis is the type which is used in this research paper and use theory as basis for data analysis. The theory includes COSO (The Committee of Sponsoring Organization) Enterprise Risk Management - Integrated Framework. The revenue cycle and expenditure cycle activities will be analyzed using process, threats, and controls enlisted in the theory. The research paper will later on propose a system and recommend control to prevent the threat that was discovered during data collection at the company.

\section{DISCUSSION}

\section{IV.I. COMPANY PROFILE}

\section{IV.I.I. COMPANY INFORMATION}

The case study of this research was conducted in a medical equipment supplier 
firm, PT. EMII. The company is located at Jl. Perintis Kemerdekaan, Perkantoran Pulomas Bl IX/6 Pulo Gadung, Jakarta. The company was founded in 1977 and started its business in supplying medical tools for hospitals and laboratory, orthopedic appliance sent to hospitals and doctors all over Indonesia until 1991.

In year 1992 the company had no longer specialized on the field of orthopedics but still on medical equipment supplier. As the time goes by, the company developed a new business field on construction and maintenance plan of wastewater treatment (IPAL) for hospitals, electrical and mechanical installation of medical gas including service and procurement of compress water machines.

\section{IV.1.2. COMPANY PRODUCT}

The company focuses his business on number of product, which are Digital blood pressure monitor, manual operating tables and medical gas central.

\section{IV.2. ACCOUNTING INFORMATION SYSTEM ANALYSIS}

\section{IV.2.1. CURRENT REVENUE CYCLE}

PT. EMII business activities are focusing on supplying medical equipment to some hospitals. Those hospitals are generally divided by two types, publicly-owned hospitals and government-owned hospitals.

The first step of revenue cycle whre price is offered to the customer. Each company's products has different range of price. The customer knows the price of the product by contacting the company or searching the information from catalog. They could, however, bargain the prices of a few products. When both parties have reached an agreement, company can issue a sales order or receive purchase order from the customer.
The goods in the warehouse can be picked out once sales order has been issued. If sales order reach out to the hands of the customer then head of finance or finance staff can inform the employees who has responsible on goods inventory in the warehouse to pick out goods that will be sold. Delivery order (DO) createdwhile picking out the goods from the warehouse. It consists of the product serial number, product name, and quantity without price tagged. Customers will receive delivery order and company keeps its copy.

When product is received by customer, then the company can further proceed on the invoice. The invoice contains product's serial number, product's name, quantity, and price. After making the invoice then company can create sales report.

The government-owned hospitals should have every transaction strictly accountably; business with government hospitals more complex than for public hospital.

There is no different of revenue cycle process between those publicly and government owned hospital.. The only different is on the inventory test where after delivering goods then customer requests to test the selling goods.

After delivering the goods completed with delivery order, customer will usually do an inventory checking/inventory test to minimize risk of damaged goods. Letter of inventory test will be produced and will sent to the company to inform that the goods are operating properly after passing the test.

The invoices are prepared after all process above have finished. The invoice contains product serial number, product name, quantity, and the price. 


\section{IV.2.2. CURRENT EXPENDITURE CYCLE}

The first step of expenditure cycle in PT. EMII is price offering from supplier. In this step, the supplier will offer a price for product by letter of price offering, especially for new supplier of for PT. EMII. When both parties have reach to an agreement then company can issue a purchase order or receive sales order from the supplier.

If purchase order issued then company may receive the invoice from supplier. The invoice contains product serial number, product name, quantity, and the price. The company pays the products in advance or pays it in cash.

\section{IV.3. THREATS AND CONTROLS}

\section{IV.3.1. THREATS AND CONTROLS IN REVENUE CYCLE}

Table 1. Threat and Controls in Revenue Cycle

\begin{tabular}{|c|l|l|l|}
\hline No & Threats & \multicolumn{1}{|c|}{ Reasons } & Controls \\
\hline 1 & $\begin{array}{l}\text { Damaged } \\
\text { goods }\end{array}$ & $\begin{array}{l}\text { The goods that were } \\
\text { picked from the storage if } \\
\text { they are not checked first, } \\
\text { they may contain }\end{array}$ & Inventory test \\
\hline 2 & $\begin{array}{l}\text { Picking the } \\
\text { irong }\end{array}$ & $\begin{array}{l}\text { After receiving the sales } \\
\text { order, there is a } \\
\text { possibility that the items } \\
\text { picked from the storage is } \\
\text { wrong } \\
\text { (different from the sales } \\
\text { order). }\end{array}$ & $\begin{array}{l}\text { Reconciliatio } \\
\text { nof picking } \\
\text { order details }\end{array}$ \\
\hline 3 & $\begin{array}{l}\text { Posting } \\
\text { errors in } \\
\text { account } \\
\text { receivable }\end{array}$ & $\begin{array}{l}\text { Possibility of posting } \\
\text { errors after } \\
\text { transaction occurred. }\end{array}$ & $\begin{array}{l}\text { Data entry } \\
\text { controls }\end{array}$ \\
\hline 5 & $\begin{array}{l}\text { Theft of } \\
\text { inventory } \\
\text { segregation } \\
\text { of duties }\end{array}$ & $\begin{array}{l}\text { The company has done } \\
\text { good } \\
\text { control to physical asset } \\
\text { and } \\
\text { inventories. }\end{array}$ & $\begin{array}{l}\text { Restriction of } \\
\text { access to } \\
\text { physical } \\
\text { assets }\end{array}$ \\
\hline many tasks. & $\begin{array}{l}\text { Company } \\
\text { should hire } \\
\text { more } \\
\text { employees. }\end{array}$ \\
\hline
\end{tabular}

\section{IV.3.2. THREATS AND CONTROLS IN EXPENDITURE CYCLE}

Table 2. Threats and Controls in Expenditure Cycle

\begin{tabular}{|c|l|l|l|}
\hline No & \multicolumn{1}{|c|}{ Threats } & \multicolumn{1}{|c|}{ Reasons } & \multicolumn{1}{c|}{ Controls } \\
\hline 1 & $\begin{array}{l}\text { Excess } \\
\text { inventory }\end{array}$ & $\begin{array}{l}\text { There could be } \\
\text { excess inventory in } \\
\text { the company if the } \\
\text { company doesn't } \\
\text { control it. }\end{array}$ & $\begin{array}{l}\text { Making a note } \\
\text { when there is a } \\
\text { supply comes } \\
\text { in }\end{array}$ \\
\hline 2 & $\begin{array}{l}\text { Lose of } \\
\text { supplier }\end{array}$ & $\begin{array}{l}\text { Supplier-company } \\
\text { relationship. }\end{array}$ & $\begin{array}{l}\text { Building } \\
\text { constant } \\
\text { relationship }\end{array}$ \\
\hline 3 & $\begin{array}{l}\text { Possible } \\
\text { loss on the } \\
\text { supply line }\end{array}$ & $\begin{array}{l}\text { Control not enough } \\
\text { when delivering } \\
\text { goods from the } \\
\text { supplier. }\end{array}$ & $\begin{array}{l}\text { Warehouse } \\
\text { control }\end{array}$ \\
\hline
\end{tabular}

\section{IV.4.1. QUESTIONNAIRE AND INTERVIEW ANALYSIS/SUMMARY}

\section{IV.4.1.1. QUESTIONNAIRE ANALYSIS}

The questionnaire respondents consists of 5 people where each of them has different post and responsibility to the company, they're head of finance, marketing manager, finance staff, sales, and secretary. Questionnaires were given one per person, without any differences where respond of each respondent.

The responds to the questionnaires of 7 COSO Enterprise Risk Management (ERM) given by 5 respondents to answer Yes (1) and No (0) are as follows :

\section{Internal environment.}

Based on the analysis to the questionnaire of internal environment, the more score $80 \%$ and above give a positive respond to the question 2 (no pressure to achieve result), 3 (reward on honesty), 4 (require to report dishonest, illegal acts and discipline) and 5 (understand code of conduct). Others, on 1 (avoiding unrealistic expectation motivated dishonest and illegal acts) and 
6 (hire competent employess) have less score, respectively $40 \%$ and $60 \%$.

According to Power (2005) the ERM is set of ideas for rethinking the organization of risk management activities where internal environment of PT. EMII was measured. The possible factors influenced the internal environment of PT. EMII are integrity, ethical values, and competence of an organization's employees, management's philosophy and operating style, the way management assigns authority and responsibility as well as organizes and develops its employees, the attention and direction provided by the board of directors (Bagranoff, Simkin and Norman, 2010).

However based on the questionnaire and interview conducted during data gathering, it was found that company has inferior internal control in certain areas. The company sometimes place too high expectation in a business that could motivate dishonest or illegal acts of employees. Director of the company prioritize on the honesty and give her trust to the employees.

\section{Objective setting.}

Based on the analysis to the questionnaire of objective setting, the more score, $80 \%$ and above give a positive respond to the question 1 (management identify ways to accomplish the strategic objectives), 2 (company ensures the accuracy, completeness, and reliability of company reports) and 4 (company comply with all applicable laws and regulations). The one, on 3 (management monitor company activities and performance) has less score, $60 \%$.

The company give very much concern on management identify to accomplish the strategic objectives), ensures the accuracy, completeness, and reliability of company reports and comply with all applicable laws and regulations. This is match with the enterprose's objective mentioned by Bagranoff, Simkin and Norman (2015) on the strategic, operation, reporting and compliance. But PT. EMII has less attention on management monitor company activities and performance)

\section{Event identification.}

Based on the analysis to the questionnaire of event identification, the more score, $80 \%$ and above give a positive respond to the question 2 (management perform internal analysis and monitoring leading events). Question 1 (incidents or occorence that affect positively to the achievement of objectives) only reach $40 \%$.

The company pay more attention to the management perform internal analysis and monitoring leading events but less attention to the possible incidents or occorence that affect positively to the achievement of objectives. Company need to give attention on a variety of uncertainties because many events are beyond the control of management, such as natural disasters, unexpected actions of competitors, and changing conditions in the marketplace etc and need as quickly as possible and then consider internal and external factors regarding each event that might affect its strategy and achievement of objectives (Bagranoff, Simkin and Norman, 2015).

\section{Risk assessment and risk response,}

Based on the analysis to the questionnaire of risk assessment and risk response, the more score $80 \%$ and above give a positive respond to the question 2 (Control system effective to reduce the risks), 3 (company accurately estimate the benefits and costs of the control). Another, on 1 (control to prevent risk available) has score $60 \%$. 
Company need have more attention on control system effective to reduce the risks and company accurately estimate the benefits and costs of the control, but less on control to prevent risk available. A variety of uncertainties because many events are beyond the control of management, such as natural disasters (Bagranoff, Simkin and Norman, 2015). Thus, a major challenge for a company implementing ERM is to ensure that decision-making not just by senior management, but by business managers throughout the firm, takes proper account of the risk-return tradeoff. (Nocco, 2006)

\section{Control activities}

Based on the analysis to the questionnaire of control activities, the more score $80 \%$ and above give a positive respond to the question 1 (proper authorization of transactions and activities), 2 (digital signature providable), 3 (transaction that requires higher management authorization), 7 (proper design and use of electronic and paper documents and records to ensure the accuracy and completeness), 8 (theft and fraud happening), 9 (physical counts properly recorded), 10 (access restriction for anyone other than employee), 11 (fireproof storage areas), and 12 (employee's performances periodically monitored by the management). Others, on 4 (policies implemented on both specific and general authorization), 5 (employee given too much responsibility over business transactions or processes), 6 (segregation of duties to the activity) have less score, $60 \%$. These are the policies and procedures that the management of a company develops to help protect all of the different assets of the firm. Control activities include a wide variety of activities throughout the firm and are typically a combination of manual and automated controls. Some examples of these activities are approval, authorizations, verifications, reconciliations, reviews of operating performance, and segregation of duties. Through properly designed and implemented control procedures, management will have more confidence that assets are being safeguarded and that the accounting data processed by the accounting system are reliable (Bagranoff, Simkin and Norman, 2010).

Regarding the accounting system, some employees do not aware on how to provide digital signature to authorize a document, which useful to minimise fraud. Segregation of duties is not well implemented andone employee can be responsible on some tasks Ahmad (2012) mentiones that a long term success of a corporation essentially depend on good and active control to provide information for internal decision making supporting company objectives

\section{Information and communication}

Based on the analysis to the questionnaire of information and communication, on 1 (files properly stored in the system), 2 (easy to access the files), and 3 (difficulties in operating the system in the computer) have $60 \%$ and below.

According to Bagranoff, Simkin and Norman (2010), managers must inform employees about their roles and responsibilities pertaining to internal control. This might include giving them documents such as policies and procedures manuals or posting memoranda on the company's intranet. This could also include training sessions for entry-level personnel and then annual refresher training for continuing employees. Based on the performance of the company, it seem the company should give more 
additional proper and adequate training to the employess.

\section{Monitoring}

Based on the analysis to the questionnaire of monitoring, the more score $80 \%$ and above give a positive respond to the question 2 (training for employees), 4 (strict supervision to employees that have access to company), 5 (system can effectively combat viruses) and 6 (transactions recorded in a log). Others, on 1 (top management often perform internal control evaluations), 3 (employees monitored by their supervisors), 7 (logs reviewed by the management), 8 (original software used), 9 (audit conduct frequently) have less score.

The company has give more attention possible training for employees, strict supervision to employees that have access to company, system can effectively combat viruses and 6 (transactions recorded in a $\log$ ). Beside these unfortunately the company should give more attention on how top management could perform internal control evaluations, employees monitored by their supervisors, logs reviewed by management, original software used, and audit conduct frequently. In order to make it better then according to Bagranoff, Simkin and Norman (2010) evaluation of internal controls should be continued. Managers at various levels in the organization must evaluate the design and operation of controls and then initiate corrective action when specific controls are not functioning properly. This could include daily observations and scrutiny, or management might prefer regularlyscheduled evaluations. The scope and frequency of evaluations depend; to a large extent on management's assessment of the risks the firm faces.

\section{IV.4.1.1. INTERVIEW ANALYSIS}

Unlike questionnaire, interview was conducted only for the director of the company. The questions in interview revolve on revenue and expenditure cycle activities done in the company. The interview was designed to finding more about the cycle activities.

\section{IV.5. RESULTS AND SUGGESTIONS}

\section{IV.5.1. PROPOSED REVENUE CYCLE}

Figure 2. Suggested revenue cycle, derived from Rama and Jones (2002)

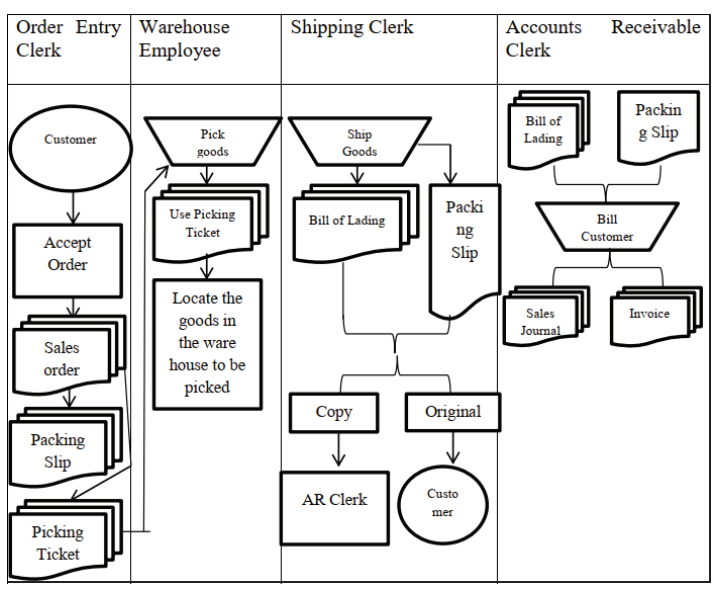

IV.5.2. PROPOSED EXPENDITURE CYCLE

Figure 3. Propose Expenditure Cycle

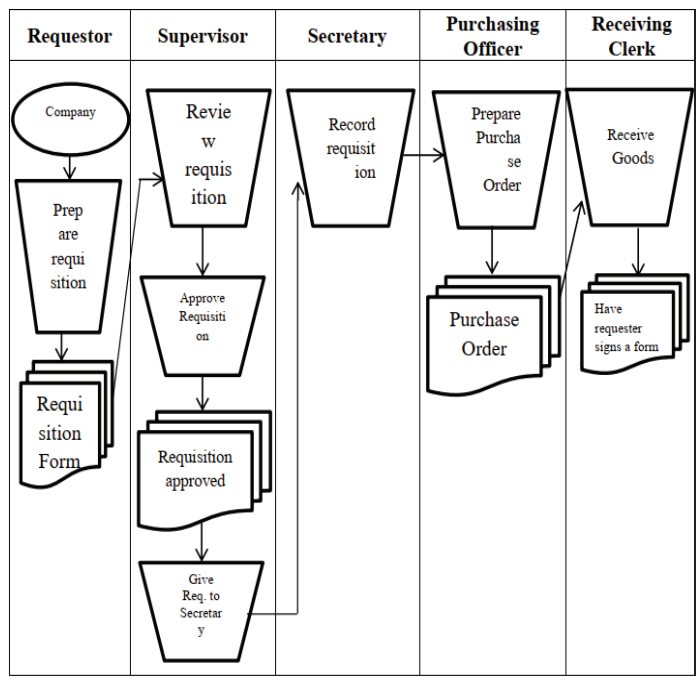




\section{IV.5.3. SUGGESTION FOR BETTER INTERNAL CONTROL}

\section{Table 3. Control Suggestion}

\begin{tabular}{|c|c|c|c|}
\hline No. & $\begin{array}{l}\text { Internal } \\
\text { Control } \\
\text { Elements }\end{array}$ & Good & Inferior \\
\hline 1 & \begin{tabular}{|l|} 
Internal \\
environment
\end{tabular} & $\begin{array}{l}\text { No pressure to achieve result), } \\
\text { reward on honesty, require } \\
\text { reporting dishonest, illegal acts } \\
\text { and disciplining and } \\
\text { understanding code of conduct. }\end{array}$ & $\begin{array}{l}\text { Avoiding unrealistic expectation } \\
\text { motivated dishonest and illegal } \\
\text { acts and hire competent } \\
\text { employess }\end{array}$ \\
\hline 2 & $\begin{array}{l}\text { Objective } \\
\text { setting }\end{array}$ & $\begin{array}{l}\text { Management identifies ways to } \\
\text { accomplish the strategic } \\
\text { objectives, company ensures the } \\
\text { accuracy, completeness, and } \\
\text { reliability of company reports } \\
\text { and company comply with all } \\
\text { applicable laws and regulations. }\end{array}$ & $\begin{array}{l}\text { Management monitor company } \\
\text { activities and performance }\end{array}$ \\
\hline 3 & \begin{tabular}{|l|} 
Event \\
identification
\end{tabular} & $\begin{array}{l}\text { Management perform internal } \\
\text { analysis and monitoring leading } \\
\text { events. }\end{array}$ & $\begin{array}{l}\text { Incidents or occorence that affect } \\
\text { positively to the achievement of } \\
\text { objectives }\end{array}$ \\
\hline 4 & \begin{tabular}{|l} 
Risk assessment \\
and risk \\
response
\end{tabular} & $\begin{array}{l}\text { Control system effective to } \\
\text { reduce the risks, company } \\
\text { accurately estimate the benefits } \\
\text { and costs of the control. }\end{array}$ & Control to prevent risk available \\
\hline 5 & \begin{tabular}{|l} 
Control \\
activities
\end{tabular} & $\begin{array}{l}\text { Proper authorization of } \\
\text { transactions and activities, } \\
\text { digital signature providable, } \\
\text { transaction that requires higher } \\
\text { management authorization, } \\
\text { proper design and use of } \\
\text { electronic and paper documents } \\
\text { and records to ensure the } \\
\text { accuracy and completeness, } \\
\text { theft and fraud happening, } \\
\text { physical counts properly } \\
\text { recorded, access restriction for } \\
\text { anyone other than employee, } \\
\text { fireproof storage areas, and } \\
\text { employee's performances } \\
\text { periodically monitored by the } \\
\text { management. }\end{array}$ & $\begin{array}{l}\text { Policies implemented on both } \\
\text { specific and general } \\
\text { authorization, employee given } \\
\text { too much responsibility over } \\
\text { business transactions or } \\
\text { processes, segregation of duties } \\
\text { to the activity }\end{array}$ \\
\hline 6 & $\begin{array}{l}\text { Information and } \\
\text { communication }\end{array}$ & None & $\begin{array}{l}\text { Files properly stored in the } \\
\text { system, easy to access the files, } \\
\text { and difficulties in operating the } \\
\text { system in the computer }\end{array}$ \\
\hline 7 & Monitoring & $\begin{array}{l}\text { Training for employees, strict } \\
\text { supervision to employees that } \\
\text { have access to company, system } \\
\text { can effectively combat viruses } \\
\text { and transactions recorded in a } \\
\text { log }\end{array}$ & $\begin{array}{l}\text { Top management often perform } \\
\text { internal control evaluations, } \\
\text { employees monitored by their } \\
\text { supervisors, logs reviewed by the } \\
\text { management, original software } \\
\text { used, audit conduct frequently }\end{array}$ \\
\hline
\end{tabular}

\section{RESULT}

\section{V.1. CONCLUSIONS}

Revenue cycle of PT. Elektro Medika International Indonesia consistes of two types, on publicly-owned hospitals and on government-owned hospitals. Both publicly and government-owned hospitals usually repeatly in the company activities with providing goods, services and collecting cash payment, including price offering to the customer, receive sales order, pick goods, shipping goods, make delivery order, prepare invoice, prepare sales report. However the government requires inventory test after initiating delivery order.

Expenditure cycle of PT. EMII consist of few main stelps, associated with the purchase of and payment for goods and services. The steps are including price offering to the supplier, confirmation letter, purchase order, receive the goods, receive documents from supplier, prepare advance payment, and make advance payment form.

PT. EMII implemented all internal control of COSO ERM model. Among those internal control, 4 of 6 questions of internal environment, 3 of 4 of objective setting, 1 of 2 event identification, 2 of 3 risk asssement and respond, 8 of 12 control activity, 0 of 2 information and communication, and 4 of 9 monitoring, of $80 \%$ and more implemented very well ( $80 \%$ and more) by PT. EMII.There were only information and communication of internal control not very well implemented (60\% and less) by the company.

PT. EMII has just implemented revenue and expenditure cycles for less than 1 year, with number of threats in the implementation of those cycles. There were possible threats found on revenue cycle namely damage goods, picking the wrong items, posting errors in account receivable, theft of inventory and no segregation of duties with proposed control were to do inventory test, reconciliation of picking lists to sales order details and data entry control, and restriction of access to physical assests respectively. Possible threats on expenditure cycle namely excess inventory lose of supplier, and possible loss on the supply line with proposed control to make note on supply, building good relationship and warehouse control respectively.

\section{V.2. RECOMMENDATIONS}

\section{V.2.1. FOR COMPANY}

It is recommended for PT. EMII to give more attention on better implementation of information and communication, 
and monitoring of the internal control compared to other 5 COSO ERM internal control's better implementation.

\section{V.2.2. FOR FUTURE RESEARCH}

Since this research is focus on a medical equipment supplier business, so it's will be very interest in having similar research on different field of business to know more impact of the accounting information system and internal control on different business sectors.

\section{REFERENCE}

Abdallah, A.A.J (2013), The Impact of Using Accounting Information Systems on the Quality of Financial Statements Submitted to the Income and Sales Tax Department in Jordan. European Scientific Journal, University of Jordan

Abadinusa - "Market Brief Indonesia Medical Equipment Business." http://www.abadinusa. co.id/news/market-brief-indonesia-medicalequipment-business, accessed April 5, 2011

Ahmad, M.A (2012), Problems and Internal Control Issues in AIS from the View Point of Jordanian Certified Public Accountants. Jordan: Journal of Emerging Trends in Computing and Information Sciences

Arens, A.A., R.J. Elder, M.S. Beasley (2012), Auditing and Assurance Services an Integrated Approach. Edinburgh Gate. Essex, USA: Pearson Education Limited

Bagranoff, N.A., M.G. Simkin., C.S. Norman (2010), Core Concepts of Accounting Information Systems 11th Edition. USA: Library of Congress Cataloging-in-Publication Data

Beasley, M.S., R. Clune, D.R. Hermanson (2005), Enterprise Risk Management: An Empirical Analysis of Factors Associated with the Extent of Implementation. The Journal of Accounting and Public Policy
Brynjolfsson, E., andL.M. Hitt(2000), Beyond computation: Information Technology, Organizational Transformation and Business Performance. Cambridge, USA: Journal of Economic Perspectives

Chung, T.T (2011), The Impact of Accounting Information on Management's Decision Making - Vinamilk Case Study. Kuala Lumpur, Malaysia: Help University

Cohen, J., G. Krishnamoorthy, A. Wright (2014), Enterprise Risk Management and the Financial Reporting Process: The Experiences of Audit Committee Members, CFOs, and External Auditors. Massachusetts, USA: International Symposium on Audit Research

Export.gov-"Healthcare Resource Guide: Indonesia" http://export.gov/industry/health/ healthcareresourceguide/indonesia084191. asp, accessed March 20, 2015

D'Arcy, S (2001), Enterprise Risk Management. Champaign, USA: University of Illinos.

Gramling, A.A., K.M. Johnstone, L.E. Rittenberg (2010), Auditing. Mason, USA: South-Western Cengage Learning

Hayne, C., C. Free (2013), Hybridize Professional Groups and Institutional Work: COSO and the Rise of Enterprise Risk Management. Canada: School of Business, Queen's University

Long, M. Internal Controls for Small Businesses to Reduce the Risk of Fraud. Plano, Texas: M. Long Consulting, LLC

Mikes (2011), Risk Management and Calculative Cultures. Boston, USA: Harvard Business School.

Mndzebele, N (2013), The Usage of Accounting Information Systems for Effective Internal Controls in the Hotels. International Journal of Advanced Computer Technology. ISSN:2319-7900 
Nocco, B.W (2006), Enterprise Risk Management: Theory and Practice. Ohio, USA: Journal of Applied Corporate Finance Volume 18 Number 4

Ofori, W (2011), Effectiveness of Internal Controls: a Perception or Reality? the Evidence of Ghana Post Company Limited in Ashanti Region. Kwame Nkrumah University of Science and Technology

Power, M(2005), Enterprise risk management and the organization of uncertainty in financial institutions. New York, USA: Oxford University Press

Paape, L., R.F. Speklé (2012), The Adoption and Design of Enterprise Risk Management Practices: An Empirical Study. Breukelen, Netherlands: European Accounting Review

Protiviti (2014), The Updated COSO Internal Control Framework Frequently Asked Questions Third Edition. Protiviti Risk and Business Consulting Internal Audit

Rama, D., F. Jones (2002), Accounting Information Systems: A Business Process Approach 1st Edition. South-Western College
Romney, M.B., P.J. Steinbart (2015), Accounting Information Systems 13th Edition. Essex, England: Pearson Education Limited

Sambasivam, Y., K.B. Assefa (2013), Evaluating the Design of Accounting Information System and its Implementation in Ethiopian Manufacturing Industries. Debre morkos, Ethiopia: The International Journal's Research Journal of Science and IT Management

Thong, J.Y.L (2000), Resource Constraints and Information Systems Implementation in Singaporean Small Businesse.Singapore: The International Journal of Management Science

Weisenfield, L.W., S. Lee, L.N. Killough. One Company's Experience with Accounting Information System Changes- an Analysis of Manager's Satisfaction.The Review of Business Information Systems

Yan, Su (2008), The Analyze on Accounting Information System of Third-party Logistics Enterprise. Shihezi, China: College of Economic and Trade, Shihezi University 